\title{
The Allemann collection from the Santa Cruz Formation (late early Miocene), Argentina, in Zurich, Switzerland
}

\author{
Daniel Zurita-Altamirano ${ }^{1}$ - Eric Buffetaut ${ }^{2,3}$ - Analía M. Forasiepi ${ }^{4} \cdot$ Alejandro Kramarz $^{5}$. \\ Juan D. Carrillo ${ }^{6,7}$ (1) - Gabriel Aguirre-Fernández ${ }^{1}$ (1) $\cdot$ Alfredo A. Carlini $^{8} \cdot$ Torsten M. Scheyer $^{1}$ (D) \\ Marcelo R. Sánchez-Villagra ${ }^{1}$ (D)
}

Received: 27 September 2018/ Accepted: 4 February 2019/Published online: 28 February 2019

(C) Akademie der Naturwissenschaften Schweiz (SCNAT) 2019

\begin{abstract}
One of the best-known faunal assemblages that characterizes the past ecosystems from South America comes from the Santa Cruz Formation in Argentina. This assemblage is formed by an endemic fauna, which included ground sloths, glyptodonts, native ungulates, terror birds (phorusrhacids), among others. The Santacrucian South American Land Mammal Age is dated 18.0-15.6 Ma, late early Miocene. Current curatorial efforts revealed a large collection of over 1100 fossil remains from the Santa Cruz Formation, donated in 2007 to the Paleontological Museum, University of Zurich, Switzerland. The fossils were brought to Switzerland in the late 1880s by Theodor Allemann, an engineer and amateur collector. The collection includes skulls, isolated teeth, mandibles, and isolated postcranial elements. Postcranials are mainly represented by astragali, calcanei, and osteoderms. The study of the remains allowed us to recognize 20 families of mammals, one of birds, and one of amphibians: Abderitidae, Palaeothentidae (Paucituberculata); Hathliacynidae (Sparassodonta); Dasypodidae, Peltephilidae, and Glyptodontidae (Cingulata); Megatheriidae and Megalonychidae (Tardigrada); Astrapotheriidae (Astrapotheria), Protherotheriidae and Macraucheniidae (Litopterna); Toxodontidae, Homalodotheriidae, Hegetotheriidae and Interatheriidae (Notoungulata); Dasyproctidae, Dinomyidae, Neoepiblemidae, Chinchillidae, Erethizontidae, Echimyidae and Eocardidae (Rodentia); Phorusrhacidae (Cariamiformes); and Calyptocephalellidae (Anura). Among them, we identified 28 genera and 9 species. Reference to the previous work on the Santa Cruz fauna and the good preservation of the material allow us to achieve taxonomic resolution in the identifications. We discuss the potential usefulness of this collection for studying the paleobiology of specimens/species of this fauna.
\end{abstract}

Keywords Mammalia $\cdot$ Aves $\cdot$ Anura $\cdot$ Miocene $\cdot$ Patagonia $\cdot$ South America

\section{Resumen}

Durante largos períodos del Cenozoico, América del Sur estuvo aislada de otros continentes y fue el hogar de una fauna endémica que incluía perezosos gigantes, gliptodontes y aves del terror (fororrácidos), entre otros. Uno de los conjuntos faunísticos más importantes que caracterizan a estos ecosistemas del pasado proviene de la Formación Santa Cruz (Edad Mamífero de América del Sur Santacrucense, 18.0-15.6 Ma, finales del Mioceno temprano. Los esfuerzos curatoriales recientes revelaron una gran colección (más de 1100 restos) de fósiles de la Formación Santa Cruz, donada por el Museo de Historia Natural Olten al Museo Paleontológico de la Universidad de Zúrich en 2007. Los fósiles fueron transportados a Suiza a fines de la década de 1880 por Theodor Allemann, un ingeniero y coleccionista aficionado, que donó su colección en 1926 al municipio de Olten. La colección incluye cráneos parciales, dientes aislados, mandíbulas, maxilares y elementos postcraneales aislados (principalmente astrágalos, calcáneos y osteodermos). La revisión de los restos nos permitió reconocer 20 familias de mamíferos, una de aves y una de anfibios: Abderitidae, Palaeothentidae (Paucituberculata); Hathliacynidae (Sparassodonta); Dasypo-

Editorial Handling: L. Costeur.

Marcelo R. Sánchez-Villagra

m.sanchez@pim.uzh.ch

Extended author information available on the last page of the article didae, Peltephilidae, y Glyptodontidae (Cingulata); Megatheriidae y Megalonychidae (Tardigrada); Astrapotheriidae (Astrapotheria), Protherotheriidae y Macraucheniidae (Litopterna); Toxodontidae, Homalodotheriidae, Hegetotheriidae y Interatheriidae (Notoungulata); Dasyproctidae, 
Dinomyidae, Neoepiblemidae, Chinchillidae, Erethizontidae, Echimyidae y Eocardidae (Rodentia); Phorusrhacidae (Cariamiformes); y Calyptocephalellidae (Anura). Hemos identificado 28 géneros y nueve especies. La referencia al trabajo previo sobre la fauna de Santa Cruz y la buena conservación del material nos permiten lograr una resolución taxonómica en las identificaciones, discutimos el potencial de esta colección para contribuir al estudio de la paleobiología de los especímenes/ especies de esta fauna

\section{Abbreviations}

$\begin{array}{ll}\text { StC }+ \text { D } & \text { Stylar cusp C + D } \\ \mathrm{StB} & \text { Stylar cusp B } \\ \mathrm{M} / \mathrm{m} & \text { Upper and lower molars } \\ \mathrm{P} / \mathrm{p} & \text { Upper and lower premolars } \\ \mathrm{C} / \mathrm{c} & \text { Upper and lower canines } \\ \mathrm{I} / \mathrm{i} & \text { Upper and lower incisors } \\ \mathrm{Mf} / \mathrm{mf} & \text { Upper and lower molariforms } \\ \text { SALMA } & \text { South America Land Mammal Age } \\ \text { PIMUZ } & \text { Paleontological Institute and Museum, } \\ & \text { University of Zurich }\end{array}$

\section{Introduction}

The South American continent was separated from other landmasses from the early Eocene (ca. $50 \mathrm{Ma}$ ) until the late Neogene when the formation of the Isthmus of Panama established a land connection between North and South America (Simpson 1980; Pascual and Ortiz-Jaureguizar 2007; Wilf et al. 2013; Cione et al. 2015; Jaramillo 2018). During this period, South America was home to an endemic fauna, which exhibited high ecological and morphological disparity. Some of the richest fossiliferous localities in South America are from the early Miocene (18.0-15.6 Ma, Perkins et al. 2012; Cuitiño et al. 2016) Santa Cruz Formation in Patagonia. The Santacrucian fauna has become one of the most studied assemblages, providing a glimpse into the past ecosystem of Patagonia at the time. The excellent preservation, completeness, and abundance of the fossil specimens made it a target for many investigations for more than 130 years. Those of the Ameghino brothers $(1887,1889,1890)$, the Princeton University Expeditions to Patagonia (1896-1899) (Scott 1905, 1909, 1910), André Tournouër's expeditions (1899-1903) for the Muséum national d'Histoire naturelle, Paris (Tournouër 1922; Buffetaut 2013), and Vizcaíno et al. (2012) in the present days are examples, just to name a few.

The early field expeditions to Santa Cruz resulted in numerous collections that were sold or given to different institutions and private collectors. Therefore, the study of the Santa Cruz Formation documents also a part of the history of paleontological research in South America (Vizcaíno 2011). Some of this history continues to come into light even today, an example is the photographic album from William B. Scott of 1901 housed in the Kansas University Natural History Museum, recently identified (Vizcaíno et al. 2017). Similarly, across European universities and museums, there are historical collections which have been either forgotten, lost, or that remain unstudied, some of them revisited only recently; for example, the collections of Egidio Feruglio (1897-1954) housed in the Museum of Geology and Paleontology of the University of Padova (Vera, Fornasiero and Del Favero 2015), and the collection of Hermann Karsten (1817-1908) housed in the Museum of Natural History of Berlin (Carrillo-Briceño et al. 2016).

Here, we report on a collection from the Santa Cruz Formation housed at the Paleontological Institute and Museum, University of Zurich. The fossils were brought to Switzerland by Theodor Allemann (01.07.1859-11.11.1931), who was a Swiss electrical engineer, director of the electric company Olten-Aarburg-Gösgen and member of the board of the Natural History Museum Olten. He graduated in 1880 from the Swiss Federal Institute of Technology of Zurich and worked in Argentina on different projects, including the harbor construction in Ensenada, La Plata, until his return to Switzerland in 1894. He donated the fossils from Argentina to the Natural History Museum Olten in 1926 (Heinz Furrer pers. comm.). That museum donated the fossils to the PIMUZ in 2007. Unfortunately, we found no records that account for the arrival of the collection in Switzerland. The collection was overlooked until it was received by PIMUZ. As a result, the only information we have about Theodor Allemann comes from his obituary published in the Schweizerische Bauzeitung (Anonymous 1931). We do not know if he assembled this collection himself, if he bought it, or both. Interestingly, since Allemann returned to Switzerland in 1894, he must have acquired his collection of Santa Cruz vertebrates close to the beginning of the paleontological exploration of the Santa Cruz Formation, since the fieldwork of Carlos Ameghino's field work in the area began in 1887, following efforts a decade earlier by Francisco P. Moreno (Vizcaíno et al. 2012). 


\section{Materials and methods}

The exact geographic provenance of the fossils cannot be traced; nevertheless, they all share the same kind of preservation and the vast majority represents the most common fossil taxa recorded in the Santa Cruz Formation. The material was analyzed and compared with published descriptions and with comparative materials housed in the Palaeontological Institute and Museum, University of Zurich (PIMUZ), the Natural History Museum, London (NHM), the Muséum National d'Histoire Naturelle, Paris (MNHN), and the Museo Argentino de Ciencias Naturales, Buenos Aires (MACN).

For descriptions, the orientation of the teeth follows Smith and Dodson (2003). We follow Soria (2001) for the taxonomy of Litopterna; Billet (2011) and Cassini et al. (2017) for Notoungulata, Scott (1905) for rodents, and Abello (2013) for Paucituberculata.

\section{Results}

The material includes 1116 fossil specimens, identified as teeth, dentaries and maxillae with dentition, partial skulls, cranial components and, postcranial bones-the latter mostly astragali and calcanei.

\section{Systematic Paleontology}

\section{Mammalia}

SPARASSODONTA Ameghino 1894

HATHLIACYNIDAE Ameghino 1894

Cladosictis Ameghino 1887

Cladosictis patagonica Ameghino 1887

Referred material PIMUZ A/V 4791 (a), right dentary with p3-m4 (Fig. 1a, b), (b) left dentary with p3; PIMUZ A/V 5661, c1; PIMUZ A/V 5662, broken dentary with c-p1.

Comments The lower canine is laterally compressed. The premolars and molars are secodont. Molars increase markedly in size from $\mathrm{m} 1$ to $\mathrm{m} 4$. Basined talonids are present in $\mathrm{m} 1-3$, which are reduced but bears small cusps in $\mathrm{m} 4$. There are two mental foramina: a large one below p2 and a small one below m1 (see also Marshall 1981). Cladosictis patagonica is the most abundant sparassodont from the Santa Cruz Formation (Prevosti et al. 2012).

Hathliacynidae indet.

Referred material PIMUZ A/V 5663, an isolated canine, PIMUZ A/V 5664, an isolated premolar.
PAUCITUBERCULATA Ameghino 1894

ABDERITIDAE Ameghino 1889

Abderites Ameghino 1887

Abderites sp.

Referred material PIMUZ A/V 5659, right dentary fragment with m2-3 (Fig. 1c, d).

Comments Short and deep dentary; $\mathrm{m} 2-3$ similar in size and shape, $\mathrm{m} 4$ absent, but likely much smaller based on the alveolus size; $\mathrm{m} 2-3$ bunolophodont, with lophs connecting labial and lingual cusps; trigonid and talonid similar in size in occlusal view and similar in height in lateral view; hypoconid not anteroposteriorly compressed; paraconid absent, as in A. meridionalis (Santacrucian age) and $A$. aisenense (Friasian sensu lato) (Marshall 1980; Abello and Rubilar-Rogers 2012).

PALAEOTHENTIDAE Sinclair 1906

Palaeothentes Ameghino 1887

Palaeothentes lemoinei Ameghino 1887

Referred material PIMUZ A/V 5660, left M2 (Fig. 1e).

Comments The left M2 has a broad crown and lacks the paracone (see Abello 2007). The tooth is smaller than the homologue in $P$. aratae and larger than that of $P$. intermedius.

PAUCITUBERCULATA indet.

Referred material PIMUZ A/V 5416, isolated left M2; PIMUZ A/V 5417, broken right dentary with broken i2 and p3.

Comments PIMUZ A/V 5416 displays the typical quadrangular shape and the four cusps of the upper molars of paucituberculatans; PIMUZ A/V 5417 resembles most the mandible shape of Palaeothentes primus, on which the alveolus of i3 is placed lateral to that of i2.

XENARTHRA Cope 1889

CINGULATA Illiger 1811

DASYPODIDAE Gray 1821

EUTATINI Bordas 1933

Proeutatus Ameghino 1891a

Proeutatus sp.

Referred material PIMUZ A/V 5584, two isolated partial osteoderms (Fig. 2m). 

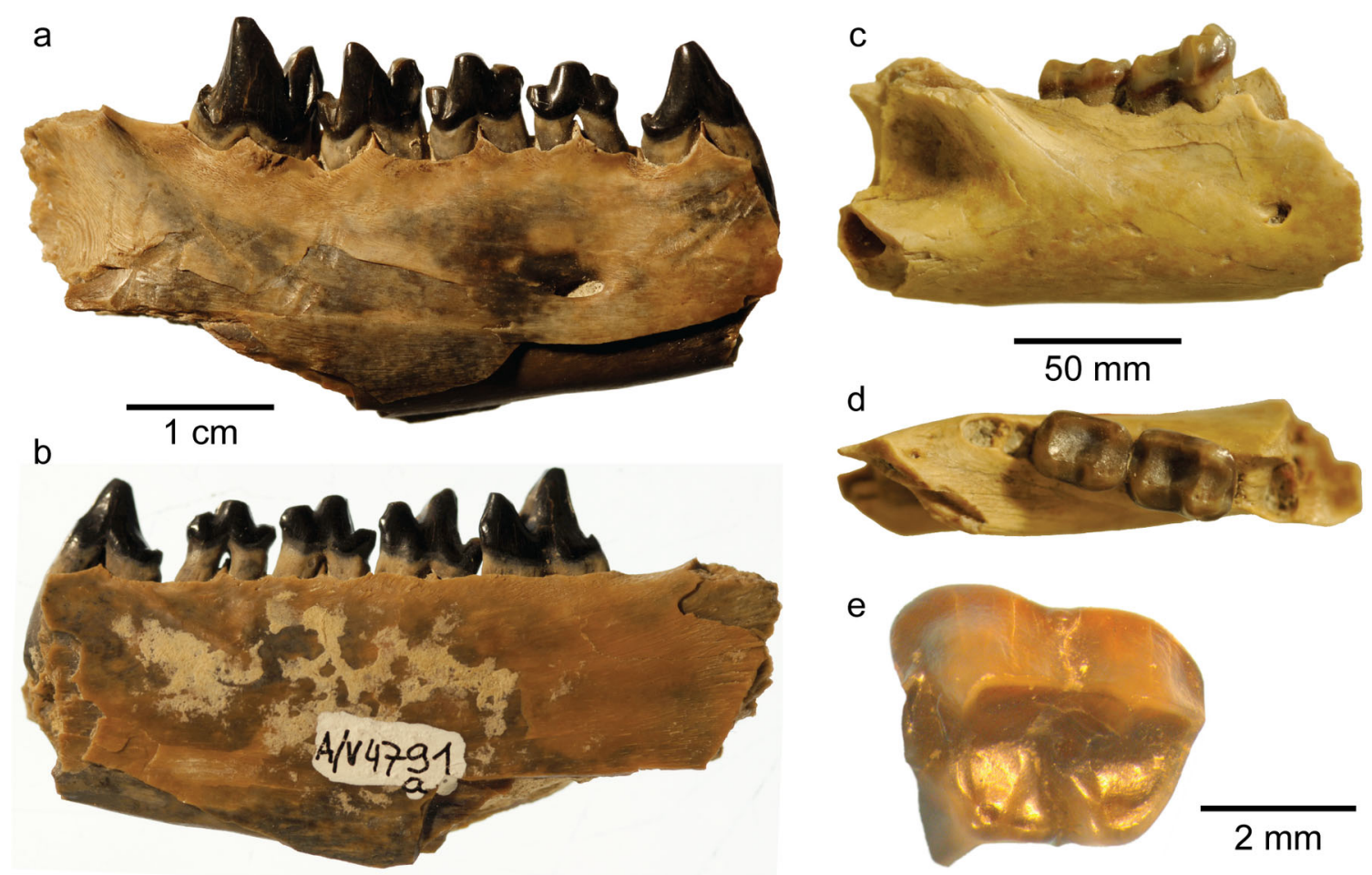

Fig. 1 a Cladosictis patagonica (PIMUZ A/V 4791) right dentary, labial view, with p3, m1-4; b same specimen in lingual view; c Abderites (PIMUZ A/V 5659) fragment of right dentary, labial view, with $\mathrm{m} 2-3$; d same specimen in occlusal view; e Palaeothentes lemoinei (PIMUZ A/V 5660) in occlusal view

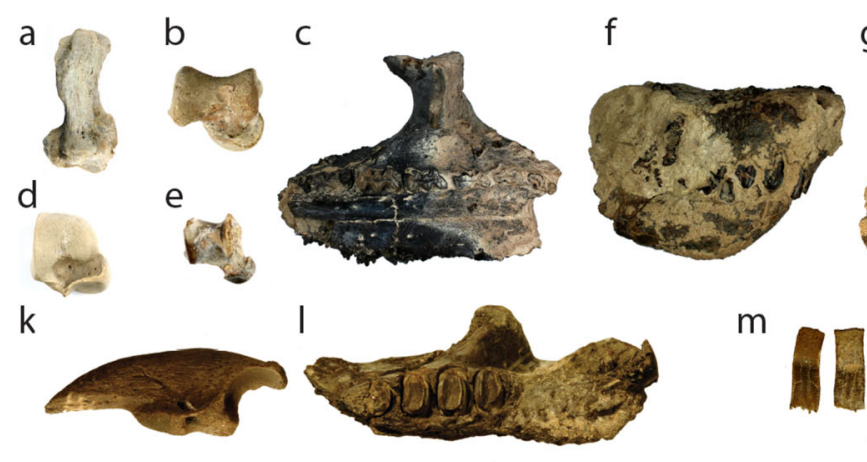

Fig. 2 a Propalaehoplophorinae indet. (PIMUZ A/V 5593) right calcaneus in ventral view; b Propalaehoplophorinae indet. (PIMUZ A/V 5594) right astragalus; c Propalaehoplophorinae indet. (PIMUZ A/V 5590) cranium with mf2-mf7 in palatal view; d Megatherioidea indet. (PIMUZ A/V 5618) right astragalus; e Dasypodidae indet. (PIMUZ A/V 5588) right astragalus (dorsal view); f Peltephilus sp. (PIMUZ A/V 5589), broken skull in right lateral view; $\mathbf{g}$ osteoderm of

Comments The well-defined lateral figures and the central figure are lageniform ("bottle shaped"), without a prominent central ridge, as is characteristic of the genus.

Stenotatus Ameghino 1891b
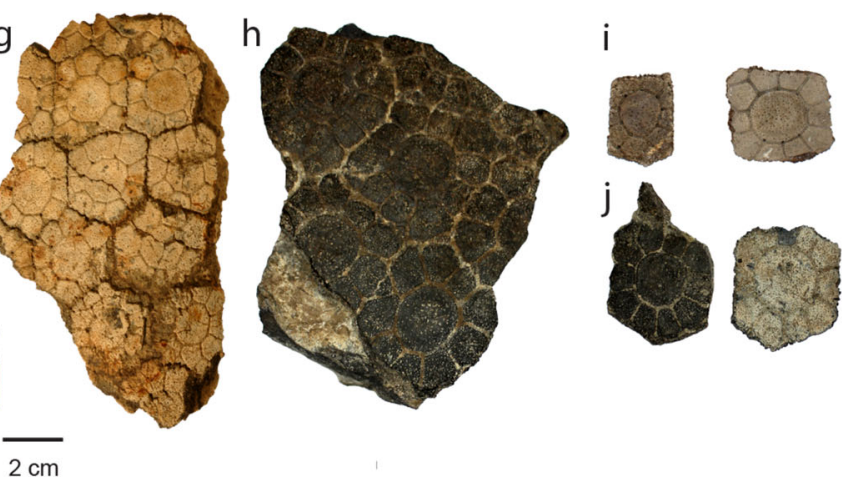

Propalaehoplophorinae indet. (PIMUZ A/V 5379); h osteoderm of Propalaehoplophorinae indet. (PIMUZ A/V 5378); i osteoderm of Propalaehoplophorinae indet. (PIMUZ A/V 5376); $\mathbf{j}$ osteoderm of Propalaehoplophorinae indet. (PIMUZ A/V 5377); k Hapalops sp. (PIMUZ A/V 5604), distal phalanx; l Hapalops sp. (PIMUZ A/V 5603) maxilla in occlusal view; m Proeutatus sp. (PIMUZ A/V 5584) osteoderms

Stenotatus patagonicus Ameghino 1887

Referred material PIMUZ A/V 5585, mobile osteoderm from the carapace. 
Comments In the exposed portion of the osteoderm three areas can be identified, two lateral with peripheral figures and a long central one.

\section{EUPHRACTINAE Winge 1923}

Prozaedyus Ameghino 1891a

Prozaedyus sp.

Referred material PIMUZ A/V 5586; PIMUZ A/V 5599, two broken isolated osteoderms.

Comments The two specimens are very small movable osteoderms, they measure $14.52 \times 4.92 \mathrm{~mm}$, and $13.52 \times 4.53 \mathrm{~mm}$, respectively, and they have a longitudinal ridge along the central figure. The osteoderms also show two almost straight longitudinal grooves with four foramina for hair follicles along them.

DASYPODIDAE indet.

Referred material PIMUZ A/V 5598, four broken osteoderms; PIMUZ A/V 5587, 21 isolated osteoderms, slightly worn; PIMUZ A/V 5588, one distal phalanx, one astragalus and two metapodials (Fig. 2e).

PELTEPHILIDAE Ameghino 1894

Peltephilus Ameghino 1887

Peltephilus sp.

Referred material PIMUZ A/V 5589, anterior portion of skull broken at the level of the frontonasal suture, with partial dentary. The first four upper teeth are observable from the right side and three from the left (Fig. 2f).

Comments The teeth are labially sharply pointed and although a small separation between them does exist, there is no proper diastema (Vizcaino and Farina 1997).

\section{GLYPTODONTIDAE Gray 1869}

Propalaehoplophorinae Ameghino 1891c

Propalaehoplophorinae indet.

Referred material PIMUZ A/V 5593 (Fig. 2a), calcaneus; PIMUZ A/V 5594 (Fig. 2b), astragalus; PIMUZ A/V 5590 (Fig. 2c), partial cranium, left side preserves six molariforms and part of the zygomatic arch. The fossil is partially covered by the matrix; PIMUZ A/V 5591, cephalic osteoderm; PIMUZ A/V 5376, 52 isolated dorsal carapace osteoderms (e.g., Fig. 2i); PIMUZ A/V 5377, 57 isolated dorsal carapace osteoderms (e.g., Fig. 2j); PIMUZ A/V 5378, seven articulated osteoderms (Fig. 2h); PIMUZ A/V 5379, 11 articulated osteoderms (Fig. 2g); PIMUZ A/V 5380 , vertebrae with imprint of the osteoderms, PIMUZ A/V 5381 and PIMUZ A/V 5657, imprint (trace in sediment) of dorsal carapace; PIMUZ A/V 5592, metacarpal.
Comments The osteoderms, of different sizes, have a central figure with nine or ten smaller polygonal peripheral figures. The grooves between figures are shallow, and mainly straight.

TARDIGRADA Latham and Davies 1795

MEGATHERIOIDEA Gray 1821

MEGATHERIIDAE Gray 1821

Planopinae Ameghino 1887

C.f. Planops sp.

Referred material PIMUZ A/V 5601, one broken distal phalanx.

Comments The phalanx is referred as c.f. Planops, because its morphology agrees with those described for "planopines" and is bigger than in Hapalops. It measures $18.41 \mathrm{~mm}$ in width and $29.25 \mathrm{~mm}$ in height at the base of the proximal articular surface and the shaft is broken.

Schismotheriinae Mercerat 1891

Hapalops Ameghino 1887

Hapalops sp.

Referred material PIMUZ A/V 5602, right maxilla (with broken Mf1-4) and dentary (broken caniniform and mf1-3); PIMUZ A/V 5603, one left dentary with four teeth (Fig. 21); PIMUZ A/V 5604, 29 distal phalanges (e.g., Fig. 2k) and one pisiform bone.

Comments The anterior-most tooth is a small caniniform. This tooth is aligned with the other teeth, is suboval in cross section, and followed posteriorly by a small diastema.

\section{MEGALONYCHIDAE Gervais 1855}

Eucholoeops Ameghino 1887

Eucholoeops sp.

Referred material PIMUZ A/V 5605, anterior fragment of left dentary (with $\mathrm{mf1}$ in place) and broken left maxilla with Mf1-4.

Comments The alveolus for the caniniform tooth is significantly larger than the other alveoli, labially dircted, and is subtriangular in cross section. In the maxilla the first tooth is placed close to the premaxillary-maxillary suture and there is a long diastema between it and the successive teeth.

Megalonychidae indet.

Referred material PIMUZ A/V 5606, fragment of dentary, only incisor alveoli are visible.

Megatherioidea indet. Gray 1821 
Referred material PIMUZ A/V 5607, one incisor; PIMUZ A/V 5422, three teeth PIMUZ A/V 5608, i1; PIMUZ A/V 5609, broken cranium; Postcranial PIMUZ A/V 5610, four phalanges; PIMUZ A/V 5611, five phalanges; PIMUZ A/V 5612, eight metapodial bones; PIMUZ A/V 5613, 10 metapodial bones; PIMUZ A/V 5614; PIMUZ A/V 5615, two metapodial bones; PIMUZ A/V 5616, nine metapodial bones; PIMUZ A/V 5617, three metapodial bones; PIMUZ A/V 5618, 17 astragali (e.g., Fig. 2d).

Tardigrada indet.

Referred material PIMUZ A/V 5620, five isolated teeth; PIMUZ A/V 5621, two broken dentaries.

\section{ASTRAPOTHERIA Lydekker 1894}

\section{ASTRAPOTHERIIDAE Ameghino 1887}

Astrapotherium Burmeister 1879

Astrapotherium magnum (Owen, 1853)

Referred material PIMUZ A/V 4663, right C1 (Fig. 3a); PIMUZ A/V 5562, three isolated teeth: left i2, right i2 and right i1; PIMUZ A/V 5563, two isolated broken teeth: p4 and m1; PIMUZ A/V 5564, P3; PIMUZ A/V 5565, broken m2-3 (Fig. 3b, c); PIMUZ A/V 5566, broken P3-M2; PIMUZ A/V 5567, broken maxilla with right and left P4M2, on both sides the P4 is broken; PIMUZ A/V 5568, left m1-3; PIMUZ A/V 5295, right m3; PIMUZ A/V 5296, six isolated broken pieces of upper molars.
Comments The dental formula of $A$. magnum is $\mathrm{I} 0 / 3, \mathrm{C} 1 / 1$, $\mathrm{P} 2 / 1, \mathrm{M} 3 / 3$. As in many other astrapotheriids (e.g., Johnson and Madden 1997; Croft 2016; Carrillo et al. 2018), the upper canines are curved and ever-growing (Scott 1928). The lower canines share this morphology, although they are much smaller. The upper molars exhibit features characteristic of this taxon, including a lingual cingulum, the hypocone/hypoflexus communicating with the central valley, and a crochet.

\section{LITOPTERNA Ameghino 1889}

PROTEROTHERIIDAE Ameghino 1887

Anisolophus Burmeister 1885.

Anisolophus floweri Ameghino 1887

Referred material PIMUZ A/V 5293, fragment of left dentary with m1-2 (Fig. 4c); PIMUZ A/V 5429 and 5430, two isolated $\mathrm{p} 4$ and one $\mathrm{m} 1$ or $\mathrm{m} 2$; PIMUZ A/V 5427, left p2-4; PIMUZ A/V 5428, m1 or m2; PIMUZ A/V 5431, right $\mathrm{M} 3$.

Comments The teeth are more massive and brachyodont than those of the other proterotheriids of the Santacrucian fauna. The material is referred to Anisolopus based on the p4 with conspicuous entoconid and thin enamel (Soria 2001). The p3-4 have a more distinct entoconid than in Tetramerorhinus (Soria 2001). In M3, the anterolabial and posterolingual cingula are prominent. The hypocone is absent. In the lower molars, the metaconoid is higher than any other cusp.
Fig. 3 Astrapotherium magnum: a PIMUZ A/V 4663, right $\mathrm{C} 1$; b PIMUZ A/V 5565, left $\mathrm{m} 3$; c same specimen, left $\mathrm{m} 2$ a

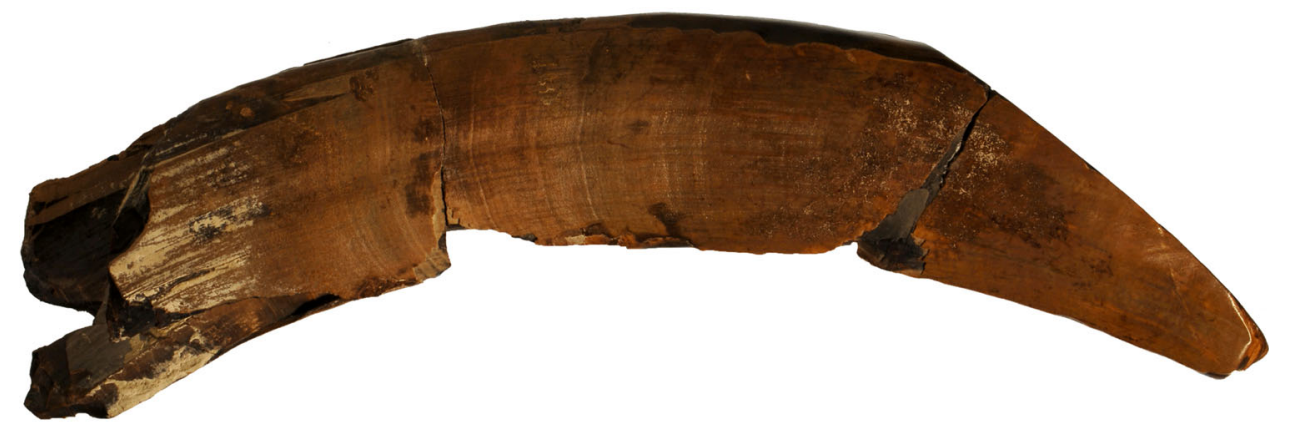

b

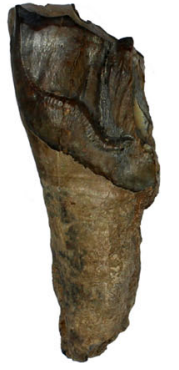

C

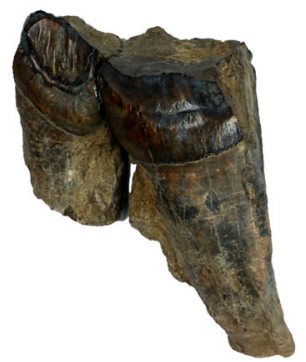

$5 \mathrm{~cm}$ 


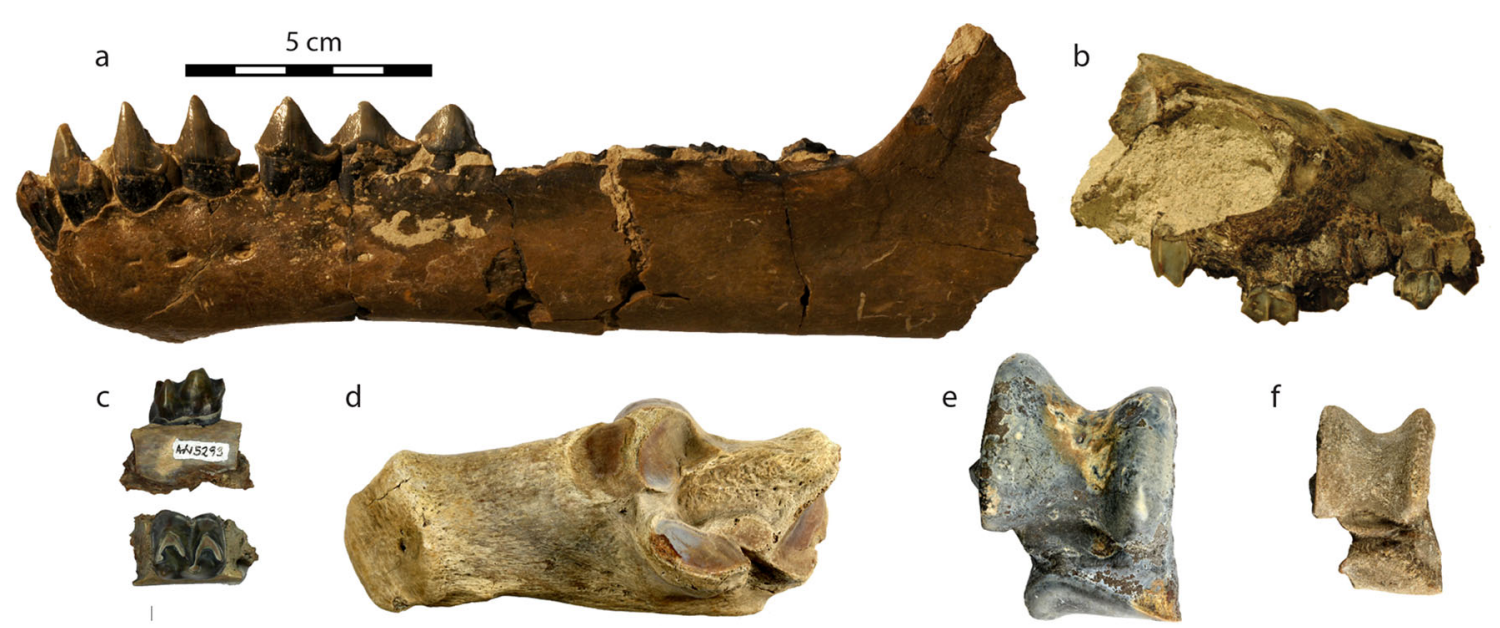

Fig. 4 a Theosodon sp. (PIMUZ A/V 4662) left dentary; b Tetramerorhinus lucarius (PIMUZ A/V 5302) cranium; c Anisolophus floweri (PIMUZ A/V 5293) left $\mathrm{ml}$; d Theosodon sp. (PIMUZ A/V

\section{Tetramerorhinus Ameghino 1894}

\section{Tetramerorhinus lucarius Ameghino 1894}

Referred material PIMUZ A/V 5294, left dentary with p3$\mathrm{m} 3$ and right dentary with p4-m1; PIMUZ A/V 5302, frontal part of the skull including the orbits (Fig. 4b), right maxilla with P2-M3 and left maxilla with P1-M1; PIMUZ A/V 5432, left maxillary fragment with M1 or M2; PIMUZ A/V 5433, four isolated molars including right M1, M2, M3 and left M2; PIMUZ A/V 5434, eight isolated premolars and molars, including one left $\mathrm{dp} 3$ or $\mathrm{dp} 4$, three right $\mathrm{p} 3$ or $\mathrm{p} 4$, one left $\mathrm{m} 1$ or $\mathrm{m} 2$, three right $\mathrm{m} 1$ or $\mathrm{m} 2$ (Table 1 ).

Comments The teeth are comparatively lower crowned than in Thoatherium and Diadiaphorus but higher than in Anisolophus. The p3-4 are molariform, they lack an entoconid, and show a marked ectoflexid. The p3-m3 share a basic form and are distinguished from one another mostly by size. The lower molars have a large paraconid. Tooth measurements fall into the range reported for Tetramerorhinus (Soria 2001).

Proterotheriidae indet.

Referred material PIMUZ A/V 5435, right P4 tooth worn; PIMUZ A/V 5438, right M1 or M2, worn, anterolingual
5426) left calcaneus; e Proterotheriidae indet. (PIMUZ A/V 5425) right astragalus; f Proterotheriidae indet. (PIMUZ A/V 5452) right astragalus cingulum present; PIMUZ A/V 5439, left P3 or P4, worn, anterolingual cingulum present; PIMUZ A/V 5440, right $\mathrm{P} 3$ or $\mathrm{P} 4$, worn, anterolingual cingulum present; PIMUZ A/V 5441, right M3, worn; PIMUZ A/V 5442, left M1 broken; PIMUZ A/V 5443, left c1; PIMUZ A/V 5444, left dentary with c1-p1; PIMUZ A/V 5445, right p1; PIMUZ A/V 5446, M1 or M2; PIMUZ A/V 5447, dentary fragment, left m1-2; PIMUZ A/V 5449, partial dentary; PIMUZ A/V 5636, maxilla fragment with M1-3 alveoli; PIMUZ A/V 5450, Left P3, worn; PIMUZ A/V 5451, right P2; PIMUZ A/V 5437, three phalanges; PIMUZ A/V 5478, phalanx II; PIMUZ A/V 5454, one small phalanx; PIMUZ $\mathrm{A} / \mathrm{V}$ 5452, seven astragali, three small ones and four smaller ones (e.g., Fig. 4f); PIMUZ A/V 5453, four isolated calcanei, two lacking the tuber calci.

Comments The variation in size among comparable material indicates that this less diagnostic material is composed many species or ontogenetic stages of single species, for example, phalanges PIMUZ A/V 5478 (mean length $4.5 \mathrm{~cm}$ ) are larger than phalanx PIMUZ A/V 5454 (length $3.6 \mathrm{~cm})$.

\section{MACRAUCHENIIDAE Gervais 1855}

Theosodon Ameghino 1887
Table 1 Dental measurements of specimens referred to Tetramerorhinus lucarius

\begin{tabular}{|c|c|c|c|c|c|c|c|c|c|c|c|c|}
\hline & \multicolumn{4}{|c|}{ PIMUZ A/V 5433} & \multicolumn{8}{|c|}{ PIMUZ A/V 5434} \\
\hline & M1 & M2 & M2 & M3 & ?p3 & ?p3 & ?dp3 & $? \mathrm{~m} 1$ & $? \mathrm{~m} 1$ & $? \mathrm{~m} 1$ & $? \mathrm{~m} 1$ & $? \mathrm{~m} 1$ \\
\hline $\mathrm{A}-\mathrm{P}$ & 11.10 & 12.24 & 12.13 & 12.10 & 11.16 & 11.74 & 11.84 & 11.94 & 12.11 & 12.39 & 13.27 & 14.16 \\
\hline B-L & 14.04 & 17.55 & 17.28 & 16.23 & 7.25 & 8.10 & 8.29 & 7.16 & 7.91 & 8.22 & 8.5 & 8.84 \\
\hline
\end{tabular}

Measurements in $\mathrm{mm}$

$A-P$ Antero-posterior, $B-L$ buccal-labial 


\section{Theosodon sp.}

Referred material PIMUZ A/V 4662 (Fig. 4a), left dentary with $\mathrm{i} 2-\mathrm{m} 3$ and right dentary with $\mathrm{i} 3-\mathrm{m} 3$ and right maxillary fragment with M1-3; PIMUZ A/V 5412, four isolated teeth, right I3, left I1-2, left I; PIMUZ A/V 5413, i1 left $\mathrm{C} 1$ right; PIMUZ A/V 5414, left $\mathrm{m} 1$ or m2; PIMUZ A/V 5420, three isolated teeth right i2, i3, c1; PIMUZ A/V 5421, right P1; PIMUZ A/V 5422, three isolated molars, right $\mathrm{M} 3$, left $\mathrm{M} 3$, left $\mathrm{M} 1$ or M2; PIMUZ A/V 5376, one complete metacarpal and 12 metacarpal heads; PIMUZ A/V 5582, nine phalanges; PIMUZ A/V 5423, anterior fragment of axis; PIMUZ A/V 5424, six phalanges; PIMUZ A/V 5425, seven isolated astragali, one with the calcaneal facet broken (Fig. 4d); PIMUZ A/V 5426, seven isolated calcanei, one without the tuber calcis (Fig. 4e).

Comments There is no cingulum between the bases of the lingual cusps of the upper molars. The M3 is more reduced in size than the M2 (Scott 1910). The wear stage of the specimen is advanced (styles are worn on M1, but still evident on M2-3). The p4 is molariform. M1 of PIMUZ A/V 4662 was used for paleohistological analysis (Forasiepi et al. 2016). The specimen has six to seven cementum lines and a thin final growth layer, suggesting a likely age of 6-8 years (Forasiepi et al. 2016). The upper molars are brachyodont, quadrangular, with a well-developed hypocone connected to the metacone by a transverse crista. M1 and M2 have a robust metastyle (de Paula Couto 1979). The $\mathrm{m} 3$ has a hypoconulid and a conspicuous entoconoid. In PIMUZ A/V 5422 (M1 or M2) the parastyle and paracone are missing and wear has erased several features of the crown.

\section{NOTOUNGULATA Roth 1903}

\section{TOXODONTIA Owen 1853}

\section{TOXODONTIDAE Owen 1845}

Nesodon Owen 1846

Nesodon sp.

Referred material PIMUZ A/V 5497, a premaxilla with I1 alveolus, and broken I2; PIMUZ A/V 5495, M2-3 with zygomatic arch; PIMUZ A/V 5496, maxilla fragment with left M1-2; PIMUZ A/V 5498, left p1-2; PIMUZ A/V 5499, two broken left m1; PIMUZ A/V 5500, three left m2; PIMUZ A/V 5501, left p4-m1, and left m3; PIMUZ A/V 5502, right p2; PIMUZ A/V 5503, right p3; PIMUZ A/V 5504, right m1; PIMUZ A/V 5505, two right m2; PIMUZ A/V 5506, four right m3; PIMUZ A/V 5507, three left and one right p3; PIMUZ A/V 5508, one left p3; PIMUZ A/V 5514, five isolated teeth, one left and one right $\mathrm{M} 2$, one left and two right $\mathrm{M} 3$, one right maxillary fragment with M2-3; PIMUZ A/V 5513, one right and two left M2, right M1-3; PIMUZ A/V 5510, four left and one right $\mathrm{M} 1$; PIMUZ A/V 5490, three right and two left $\mathrm{p} 4$; PIMUZ A/V 5512, one left p2 and one right p3; PIMUZ A/V 5513, five isolated teeth, two P3, one left, one right, two P4, one right, one left, left P4 fragment; PIMUZ A/V 5516, petrosal bone; PIMUZ A/V 5520, left dentary fragment with broken p3-m2; PIMUZ A/V 5521, two fragments of parietal bone with sagittal crest; PIMUZ A/V 5522, cranial fragment including portions of the zygomatic arch and broken M1-3; PIMUZ A/V 5524, premaxilla; PIMUZ A/V 5525, right fragmentary maxilla with broken P1-4; PIMUZ A/V 5526, right maxilla fragment with broken P2-4; PIMUZ A/V 5527, partial skull with sagittal crest; PIMUZ A/V 5528, left skull fragment with M1-3 and broken zygomatic arch; PIMUZ A/V 5529, right dentary fragment with m2-3; PIMUZ A/V 5530, broken left maxilla with M1-3 and base of zygomatic arch; PIMUZ A/V 5531, skull fragment with incomplete premaxilla, nasal notch and tooth alveoli; PIMUZ A/V 5532, cranial fragment including portions of the occipital region and basicranium; PIMUZ A/V 5533, anterior portion of premaxilla with portion of the maxilla; A/V 5297, left broken dentary with p2-m3, right m3; A/V 5298 (Fig. 5a), left broken dentary with p2-m3; A/V 5299, M2-3; PIMUZ A/V 5514, three phalanges; PIMUZ A/V 5515, one metatarsal; PIMUZ A/V 5517, six astragali (Fig. 5c); PIMUZ A/V 5518, five calcanei (Fig. 5b).

Comments The imbrication of the upper molars is distinct. The teeth are hypsodont, roots become obvious above the alveolar margin in older individuals. Nesodon has a longer anterior projection of the nasal bone than does Adinotherium, although as pointed out by Scott (1909), exceptions are common. The sagittal crest is formed by two parallel sharp and thin ridges. Nesodon is one of the most common genera in the Allemann collection.

Adinotherium Ameghino 1887.

Adinotherium sp.

Referred material PIMUZ A/V 5460, three broken maxillae; PIMUZ A/V 5461, broken maxilla; PIMUZ A/V 5462, cranial fragment including portions of the occipital and parietal regions; PIMUZ A/V 5463, smashed skull; PIMUZ A/V 5464, right p2; PIMUZ A/V 5467, broken part of right maxilla with M1 or M2; PIMUZ A/V 5468, left M3 broken; PIMUZ A/V 5469, right P4-M1; PIMUZ A/V 5470, broken right M3; PIMUZ A/V 5471, left maxillary fragment with M1-3 and part of zygomatic arch; PIMUZ A/V 5472, left P2-3; PIMUZ A/V 5473, right P4-M3; PIMUZ A/V 5474, left maxilla with P3-M2, infraorbital foramen, and the base of zygomatic arch; PIMUZ A/V 5475, left maxilla fragment with M2-3; PIMUZ 

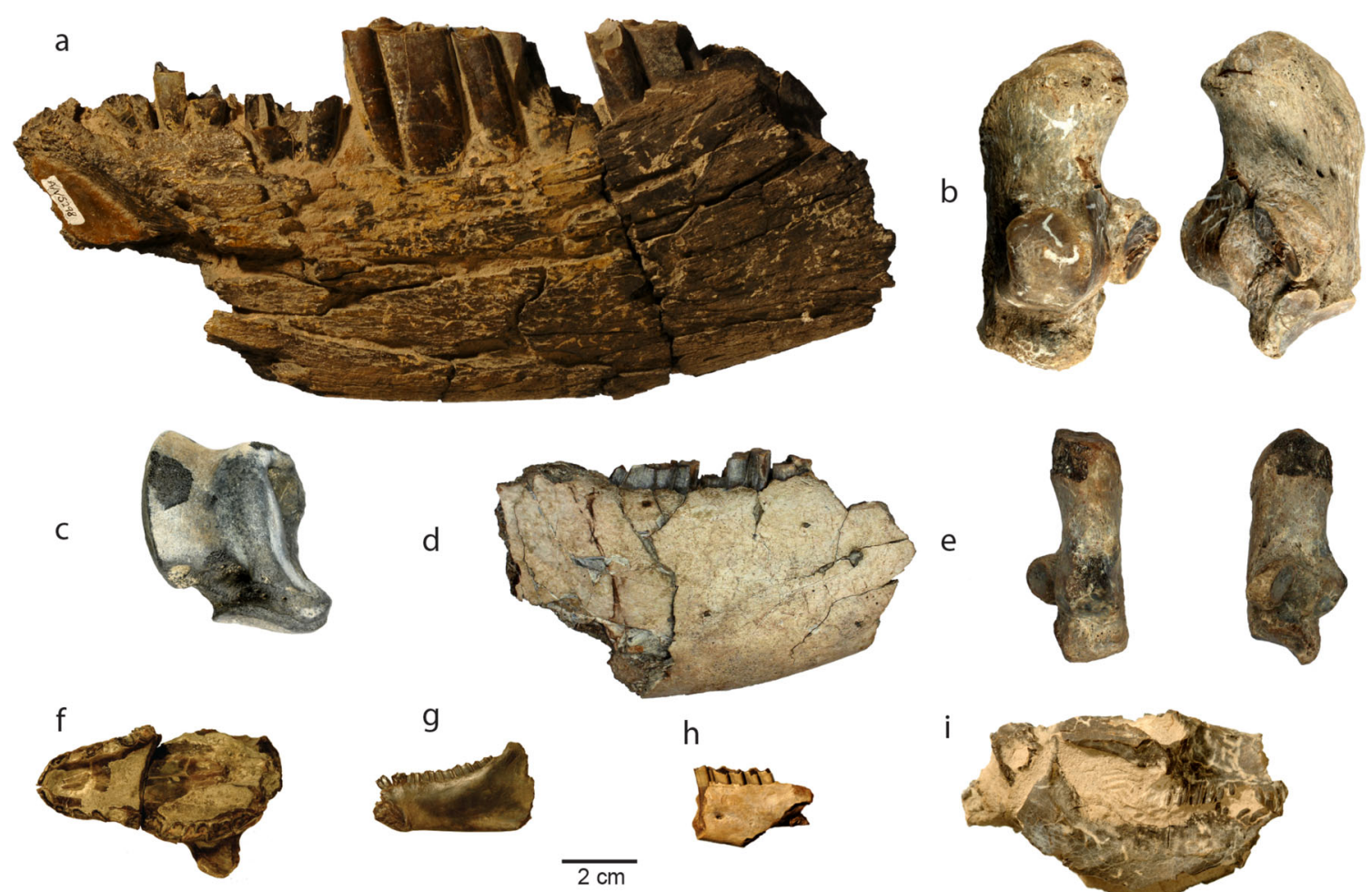

$\mathrm{h}$

Fig. 5 a Nesodon imbricatus (PIMUZ A/V 5298) left dentary; b Nesodon imbricatus (PIMUZ A/V 5518) right calcaneus in dorsal and medial views; c Nesodon imbricatus (PIMUZ A/V 5517) right astragalus in dorsal view; d Adinotherium sp. (PIMUZ A/V 5483) right dentary; e Adinotherium sp. (PIMUZ A/V 5466) left calcaneus

in dorsal and medial views; f Protypotherium sp. (PIMUZ A/V 5551) skull in palatal view; g Protypotherium sp. (PIMUZ A/V 5553) left dentary; h Interatherium sp. (PIMUZ A/V 5543) left dentary; i Interatherium sp. (PIMUZ A/V 5547) skull including mandible

A/V 5476, broken part of right maxilla with M2-3; PIMUZ A/V 5477, broken part of right maxilla with M1-3, base of the zygomatic arch; PIMUZ A/V 5478, broken left m3; PIMUZ A/V 5479, premaxilla fragment with showing only left and right I2; PIMUZ A/V 5480, two isolated teeth, left and right M3; PIMUZ A/V 5658, five isolated teeth, three right, two left M2; PIMUZ A/V 5481, seven isolated teeth, one left, six right M1; PIMUZ A/V 5482, broken right dentary; PIMUZ A/V 5483, nine broken dentaries (one shown in Fig. 5d); PIMUZ A/V 5484, fragment of left I2; PIMUZ A/V 5485, three isolated teeth; PIMUZ A/V 5486, five isolated teeth, three left, two right P3; PIMUZ A/V 5487, four isolated $\mathrm{P} 2$, one left, three right; PIMUZ A/V 5488, four isolated P1, one left, three right; PIMUZ A/V 5489, three isolated right teeth, P2,P3,P4; PIMUZ A/V 5490, left M3, one left M2 and one right M2-3; PIMUZ A/V 5491, left p3; PIMUZ A/V 5492, eight isolated teeth: three right $\mathrm{p} 2$, one left $\mathrm{p} 2$, two left $\mathrm{p} 3$, one right p3, one left p4; A/V 5301, right M1-3; A/V 5300, left P3M2; PIMUZ A/V 5493, cranial fragment including portions of the maxilla with broken P2-M3; PIMUZ A/V 5494, frontal bone fragment; PIMUZ A/V 5466, four astragali (Fig. 5e); PIMUZ A/V 5465, three calcanei.

Comments The postcranial elements of Adinotherium are smaller than those of Nesodon. The astragalus of Adinotherium is proportionally narrower and longer than in Nesodon: the neck of the astragalus is longer and more oblique, projecting more to the tibial side. The calcaneus of Adinotherium is proportionally slender, longer and more compressed than in the genus Nesodon (Scott 1909).

\section{HOMALODOTHERIIDAE Ameghino 1889}

\section{Homalodotherium Flower 1873}

\section{Homalodotherium sp.}

Referred material PIMUZ A/V 5534, left calcaneus.

Comments Although the calcaneus is the biggest one in the collection (133.80 mm maximum length of the calcaneus, $50.58 \mathrm{~mm}$ minimum dorsoplantar distance of the tuberosity), the epiphysial plate is not completely fused. In most, but not all clades of mammals, this is characteristic of animals that have not yet reached sexual maturity (Geiger et al. 2014). It is elongated in the dorsal-plantar axis and thin in the medio-lateral axis. 
Toxodontia indet.

Referred material PIMUZ A/V 5462, Premaxilla fragment with broken left I1, right I1-2.

\section{TYPOTHERIA Zittel 1893}

\section{HEGETOTHERIIDAE Ameghino 1894}

Hegetotherium Ameghino 1887

\section{Hegetotherium sp.}

Referred material PIMUZ A/V 5537, 16 molars and premolars; PIMUZ A/V 5538, 13 broken dentaries.

Comments The p3 and p4 are molariform, there is no labial sulcus, and they have a well-developed lingual sulcus forming the bridge between the trigonid and talonid on the labial side. The labial side of both trigonid and talonid is flat, whereas the lingual side of the trigonid is rounded and the talonid is triangular in cross section (Cassini et al. 2017).

\section{INTERATHERIIDAE Ameghino 1887}

\section{Interatherium Ameghino 1887}

\section{Interatherium $\mathrm{sp}$.}

Referred material PIMUZ A/V 5543, four dentaries (one of them illustrated in Fig. 5h); PIMUZ A/V 5544, two broken skulls; PIMUZ A/V 5545, broken cranium with left P3-M3 and right P3-M3; PIMUZ A/V 5546, broken cranium with left P2-M3; PIMUZ A/V 5547, broken skull, including mandible (Fig. 5i).

Comments Unlike Hegetotherium, the sulcus between the paracone and parastyle is present on the molars and P3-4. The lower dentition shows well-developed labial and lingual sulci. The bridge between the trigonid and talonid is formed close to the center of the teeth (Cassini et al. 2017).

Protypotherium Ameghino 1885

Protypotherium sp.

Referred material PIMUZ A/V 5551, broken cranium (Fig. 5f); PIMUZ A/V 5548, 44 isolated premolars and molars; PIMUZ A/V 5552, partially broken cranium; PIMUZ A/V 5549, 4 broken maxillae; PIMUZ A/V 5550, 25 broken dentaries; PIMUZ A/V 5553, left dentary (Fig. 5g).

Comments The incisors and the canines share a similar shape and size, in contrast to Interatherium and Hegetotherium. The sulcus between the paracone and parastyle is only deep in the premolars. In the lower dentition, the talonid is bigger than the trigonid in the molars and this relationship is reversed in the premolars. The bridge between the trigonid and talonid is formed close to the labial side of the teeth, giving an asymmetrical occlusal view with a deep labial sulcus and a lingual groove (Cassini et al. 2017).

Typotheria indet.

Referred material PIMUZ A/V 5559, broken mandible, right i1; PIMUZ A/V 5557, i2; PIMUZ A/V 5638, small i1or i2; PIMUZ A/V 5539, three calcanei; PIMUZ A/V 5540, two astragali; PIMUZ A/V 5541, two calcanei; PIMUZ A/V 5555, 13 calcanei; PIMUZ A/V 5554, ten astragali; PIMUZ A/V 5558, seven astragali, PIMUZ A/V 5560 one phalanx; PIMUZ A/V 5561, three phalanges.

RODENTIA Bowdich 1821

HYSTRICOGNATHI Tullberg 1899

CAVIOMORPHA Wood 1955

\section{DASYPROCTIDAE Smith 1842}

Neoreomys Ameghino 1887

Neoreomys australis Ameghino 1887

Referred material PIMUZ A/V 5569, 12 lower molars; PIMUZ A/V 5570, three right deciduous lower premolars; PIMUZ A/V 5571, five upper molars; PIMUZ A/V 5572, $34 \mathrm{~m} 1$ or m2; PIMUZ A/V 5573, 13 P4, M1 or M2, and M3; PIMUZ A/V 5265, skull, the incisors are broken but still are distinctly slightly convex (Fig. 6e); PIMUZ A/V 5273 left $\mathrm{m} 1-2$. The alveolus of the incisor below the $\mathrm{m} 1-2$ is observable; a broken portion of the $\mathrm{m} 3$ is preserved.

Comments The upper molars have a pentalophodont occlusal pattern only observable in juveniles. The P4 is divided in two parts, separated by enamel. The teeth identified as M1 or M2 have a marked hypoflexus separating the anterior and the posterior lobe. They have three fossettes, without cement within them. The lower molars are bilobed with triangular prisms ending in sharp lingual apices. The lingual margin has no groove, whereas on the labial side there is a deep continuous hypoflexid along the crown.

DINOMYIDAE Alston 1876

Scleromys Ameghino 1887

Scleromys cf. osbornianus Ameghino 1894

Referred material PIMUZ A/V 5270, right dentary with p4-m2 (Fig. 6c).

Comments All teeth show fossetids smaller than in Neoreomys. The $\mathrm{p} 4$ and $\mathrm{m} 2$ have a strong hypoflexid on the labial side that divides the teeth in two parts. The $\mathrm{m} 1$ is more quadrangular than the other molars and it has no flexid; instead there are two enamel lakes. 
Fig. 6 a Steiromys detentus (PIMUZ A/V 5271) left dentary with m1-2; b Perimys sp. (PIMUZ A/V 5266) left dentary with i1 and p4-m3; c Scleromys cf. osbornianus (PIMUZ A/V 5270) right dentary with $\mathrm{p} 4-\mathrm{m} 2$ d Prolagostomus sp. (PIMUZ A/V 5269) left dentary $\mathrm{p} 4-\mathrm{m} 1$; e Neoreomys australis (PIMUZ A/V 5265), partial skull in occlusal view

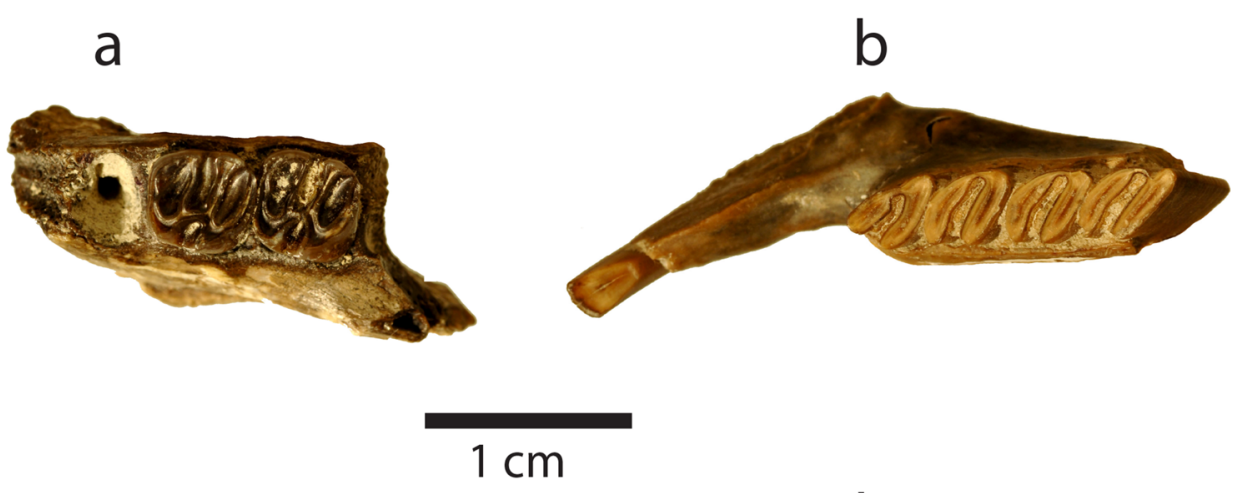

C
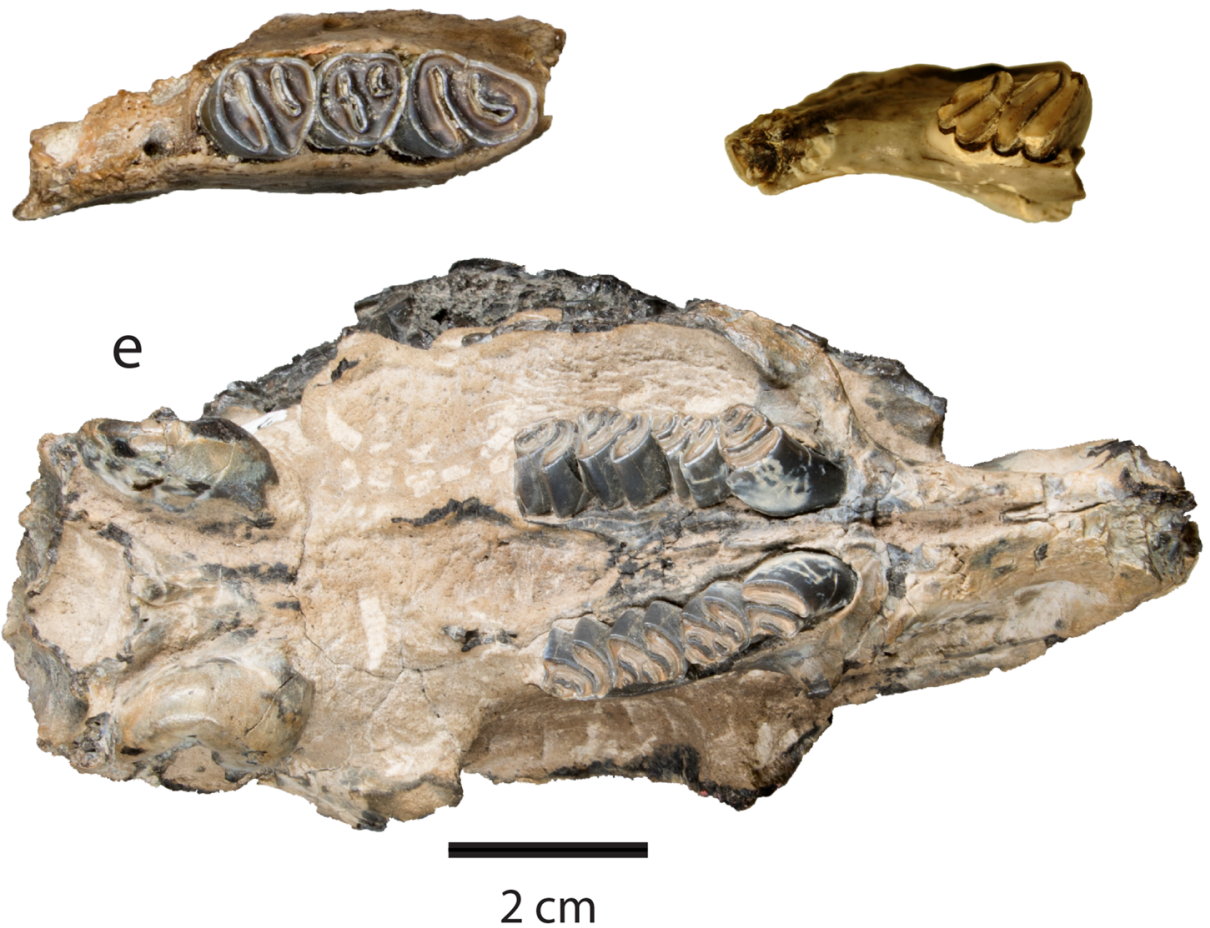

CHINCHILLOIDEA Bennett 1833

NEOEPIBLEMIDAE Kraglievich 1926

Perimys Ameghino 1887

Perimys sp.

Referred material PIMUZ A/V 5266, left dentary with i1 and p4-m3 (Fig. 6b); PIMUZ A/V 5267, left dentary with p4 and m1-2, the crowns are broken; PIMUZ A/V 5268, partial right dentary with broken $\mathrm{i} 1$, and $\mathrm{m} 1-2$, plus 17 isolated teeth.

Comments The teeth are hypselodont. The p4 is the smallest and most triangular cheek tooth. All teeth are bilobed with cement filling the valley between the laminae. The valley opens on the labial side with a long visible wide groove. The tooth series is obliquely oriented. On the lingual side, there is a thin enamel bridge connecting the laminae that are surrounded by enamel. The $\mathrm{m} 1$ is larger than $\mathrm{m} 2$.

CHINCHILLIDAE Bennett 1833

Prolagostomus Ameghino 1887

Prolagostomus sp.

Referred material PIMUZ A/V 5269, left dentary with broken incisor, p4-m1 (Fig. 6d).

Comments The teeth are bilaminar and hypselodont. The $\mathrm{p} 4$ is smaller and is more triangular in shape than the $\mathrm{m} 1$, but in both teeth, the lingual side is shorter than the labial one. The laminae are oblique. The long transverse interlaminar valleys are narrow and extend from the labial to the lingual margin. No cement is visible. The laminae of the $\mathrm{m} 1$ are 
broader. The lingual side of the teeth is smooth. The labial side has a thin groove.

\section{ERETHIZONTIDAE Thomas 1897}

Steiromys Ameghino 1887

Steiromys detentus Ameghino 1887

Referred material PIMUZ A/V 5574, 3 isolated teeth: m1 or m2, M1 or M2, and M3; PIMUZ A/V 5271, left dentary with m1-2 (Fig. 6a); PIMUZ A/V 5272, right dentary with $\mathrm{m} 1-2$.

Comments Steiromys, like other erethizontids, has typically broader enamel covering the cheek teeth than in other caviomorphs. The molars are tetralophodont and low crowned, $\mathrm{m} 1$ and $\mathrm{m} 2$ are roughly the same size and have the same occlusal pattern. The molars are surrounded by an enamel wall and each lobe contains an enamel lake on its lingual side.

The valley on the lingual side is more penetrating, shallower, and more transverse than the valley on the labial side. The anterior margin is straight while the posterior one is convex.

OCTODONTOIDEA Waterhouse 1839

ECHIMYIDAE Gray 1825

Spaniomys Ameghino 1887

Spaniomys cf. riparius Ameghino 1887

Referred material PIMUZ A/V 5575, three dentaries, two left ones and one right for $S$. cf. riparius.

Spaniomys cf. modestus Ameghino 1887

Referred material PIMUZ A/V 5576, one right dentary.

Comments Tetralophodont teeth; $\mathrm{p} 4, \mathrm{~m} 1$ and $\mathrm{m} 2$ showing three internal folds and $\mathrm{m} 3$ only two.

EOCARDIDAE Ameghino 1891d

Eocardiidae indet.

Referred material PIMUZ A/V 5577, 11 molars; PIMUZ A/V 5578, fragment of dentary, P4-M2.

Comments The dentary seems to be from a juvenile Eocardiidae, cf. Eocardia or cf. Schistomys.

Rodentia indet.

Referred material PIMUZ A/V 5581, tooth fragments; PIMUZ A/V 5582, 17 incisors; PIMUZ A/V 5454, one phalanx; PIMUZ A/V 5583, six metapodials.

Mammalia indet.

Referred material PIMUZ A/V 5607, right i1 PIMUZ A/V 5624, isolated right I1; PIMUZ A/V 5627, isolated right i1;
PIMUZ A/V 5627, isolated right I1; PIMUZ A/V 5634, isolated tooth; PIMUZ A/V 5647, left i1.

Aves.

The avian material in the Allemann collection consists of 49 specimens in a variable state of preservation. Some are extremely fragmentary and can be identified as avian mainly on the basis of the highly cancellous nature of the bone. All specimens are indicative of large birds and all the bones that can be identified are referable to Phorusrhacidae.

CARIAMIFORMES Verheyen 1957

PHORUSRHACIDAE Ameghino 1889

Patagornis Moreno and Mercerat 1891

Patagornis marshi Moreno and Mercerat 1891

Referred material PIMUZ A/IV 125, fragment of premaxilla; PIMUZ A/IV 126, two fragments of pelvis (that may belong to a single individual); PIMUZ A/IV 141, fragmentary distal end of femur; PIMUZ A/IV 123, proximal end of fibula, distal end of tibiotarsus, PIMUZ A/IV

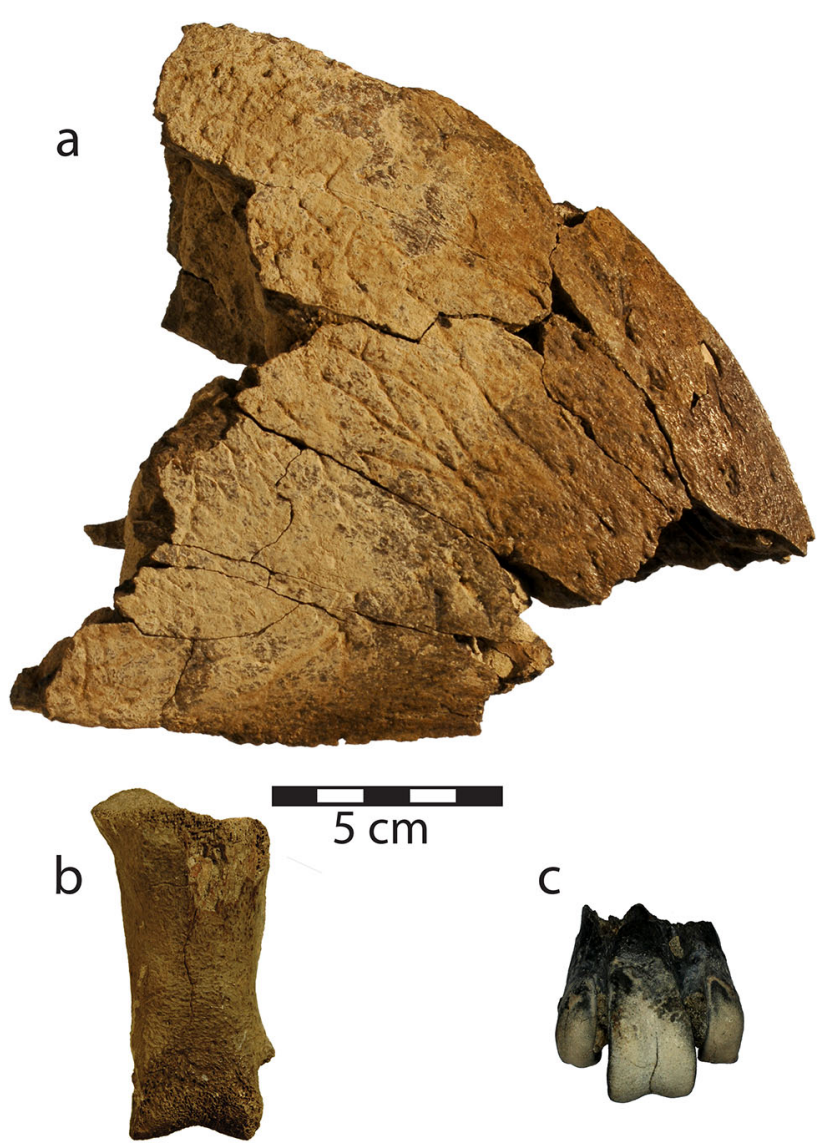

Fig. 7 a Phorusrhacos longissimus (PIMUZ A/IV 122) rostrum fragment in right lateral view; b Phorusrhacos longissimus (PIMUZ A/IV 130), phalanx; c Patagornis marshi (PIMUZ A/IV 121), distal end of tarsometatarsus 
120, proximal end of tarsometatarsus; PIMUZ A/IV 124, fragment of scapula, PIMUZ A/IV 121, distal end of metatarsus (Fig. 7c); PIMUZ A/IV 139, distal end of metatarsus; PIMUZ A/IV 140, fragment of tarsometatarsus; PIMUZ A/IV 131, long bone fragment.

Comments Most of the identifiable avian material in the Allemann collection are referable to the medium-sized phorusrhacid Patagornis marshi. The aforementioned specimens have the same morphology as Patagornis marshi (Alvarenga and Höfling 2003) (e.g., NHM A516, a partial skeleton with a well-preserved skull from the Santa Cruz Formation) originally described as Phororhacos inflatus by Ameghino (1895) and Andrews (1899). However, the postcranial skeleton of phorusrhacids is rather similar in the various taxa of this group, and as the phorusrhacid assemblage from the Santa Cruz Formation includes several taxa (see Degrange et al. 2015 for a recent review), attribution to Patagornis marshi solely on morphological criteria is difficult, and size can be used as a distinguishing feature. The smallest phorusrhacids from the Santa Cruz Formation are the psilopterines Psilopterus lemoinei and P. bachmanni, which are significantly smaller than Patagornis marshi (Degrange et al. 2015). The aforementioned specimens appear to be too large to be referred to any of the Santa Cruz psilopterines as described by Ameghino (1895), Sinclair and Farr (1932) and Degrange and Tambussi (2011). Conversely, they agree well with the dimensions of Patagornis marshi provided by Andrews (1899), as shown by a comparison with the specimens from the Allemann collection for which reasonably accurate measurements can be taken (Table 2). Similarly, the pelvic fragments are similar in size to the corresponding parts of NHM A516. On this basis, it seems reasonable to refer the aforementioned specimens to Patagornis marshi.

\section{Phorusrhacos longissimus Ameghino 1887}

Referred material PIMUZ A/IV 122, fragmentary rostrum (Fig. 7a); PIMUZ A/IV 130, a pedal phalanx (Fig. 7b); PIMUZ A/IV 129, two incomplete vertebrae.

Table 2 Size comparison between specimens referred to Patagornis marshi (PIMUZ A/V 141, PIMUZ A/V 139) and the type specimen of Patagornis marshi (NHM A516)

\begin{tabular}{lcl}
\hline & Allemann collection & $\begin{array}{l}\text { NHM } \\
\text { A516 }\end{array}$ \\
\hline Distal width of tibiotarsus & $\begin{array}{c}44 \mathrm{~mm} \text { (PIMUZ A/V } \\
141)\end{array}$ & $43 \mathrm{~mm}$ \\
& $47 \mathrm{~mm}$ (PIMUZ A/V & $47 \mathrm{~mm}$ \\
$\begin{array}{l}\text { Proximal width of } \\
\text { tarsometatarsus }\end{array}$ & $139)$ & $44 \mathrm{~mm}$ \\
\hline
\end{tabular}

Comments The poorly preserved vertebrae may belong to the cervical series. One has an anterior width of $56 \mathrm{~mm}$, which is in the size range of the vertebrae described by Ameghino (1895) as belonging to Phorusrhacos longissimus, one of which had an anterior articular face $51 \mathrm{~mm}$ in width.

The phalanx is the first phalanx of the middle (third) toe. It is $75 \mathrm{~mm}$ in length, whereas the corresponding element is $55 \mathrm{~mm}$ long in the Patagornis marshi specimen (NHM A516) described by Ameghino (1895) and Andrews (1899). The specimen from the Allemann collection is very similar in morphology and dimensions to a large phalanx from the Santa Cruz Formation referred to 'Phororhacos' sp. by Sinclair and Farr (1932, pl. XXXIV).

The rostrum fragment corresponds to a fairly anterior portion of the premaxillae, missing the downturned, hooklike tip. What is left of the ventral margin is straight in lateral view, whereas the dorsal margin (culmen) is smoothly rounded. The rostrum was clearly tall and very narrow, as in all phorusrhacids: its maximum height is $155 \mathrm{~mm}$ (but the specimen is incomplete dorsally) and its maximum width at the level of the palate is $40 \mathrm{~mm}$. The upper jaw of Patagornis marshi, NHM A516 is $117 \mathrm{~mm}$ deep at its middle point. This means that the specimen from the Allemann collection was at least 50\% larger than NHM A516, which shows no evidence of being a juvenile (the Patagornis marshi skull MLP-84-III-9-21 figured by Alvarenga and Höfling (2003, Fig. 27) is of very similar size to NHM A516). Unless one postulates a very significant but hitherto undetected intraspecific variability or sexual dimorphism in Patagornis marshi, it seems legitimate to refer that rostrum to a different avian species. The largest bird in the Santa Cruz avifauna is Brontornis burmeisteri, a possible anseriform (Agnolin 2007; Buffetaut 2014; but see Worthy et al. 2017 for a different opinion), for which the rostrum is not known. However, Brontornis burmeisteri has a wide lower jaw (Alvarenga and Höfling 2003; Agnolin 2007; Buffetaut 2014), which implies that its upper jaw must also have been wide, unlike the proportionally very narrow rostrum from the Allemann collection. Another very large bird from the Santa Cruz Formation is the phorusrhacid Phorusrhacos longissimus Ameghino 1887. While a nearly complete lower jaw of that species is known (NHM A529), the associated skull could not be collected as it fell to pieces when discovered and only the hook-shaped tip of the premaxillae and an element of the posterior part of the skull could be salvaged (Ameghino 1895). Ameghino (1895) published a reconstruction of the skull and claimed that the rostrum was $25 \mathrm{~cm}$ deep at its posterior part. The specimen in the Allemann collection would appear to be smaller but it should be remembered that it is not from the posterior part 
of the rostrum, and, perhaps more importantly, that Ameghino's estimate can only have been a rough approximation. His reconstruction is simply an enlargement of the skull of Patagornis marshi (then considered as a smaller species of Phorusrhacos, P. inflatus), and although it was widely accepted and reproduced (often as a "natural-size" plaster model that can still be seen in various museums), it is by no means certain that it provides a realistic depiction of what the skull of Phorusrhacos longissimus was like. As noted by Agnolin (2016), the largest phorusrhacids, such as Onactornis and Kelenken, had a relatively low and elongate beak that was rather different from the tall beak of Patagornis and Andalgalornis (Fig. 8). The fact that the rostrum from the Allemann collection is not as deep as the estimate for Phorusrhacos longissimus from Ameghino, thus does not necessarily imply that it cannot be referred to that taxon. In view of its large size, that significantly exceeds that of known specimens of Patagornis marshi, it seems reasonable to refer it to the largest phorusrhacid taxon known from the Santa Cruz Formation, Phorusrhacos longissimus.

Aves indet.

Referred material PIMUZ A/IV 131, long bone fragment; PIMUZ A/IV 132, fragment of distal end of femur; PIMUZ A/IV 135, two fragments of postzygapophysis; PIMUZ A/IV 133, three fragments of vertebrae; PIMUZ A/IV 136, bone fragment; PIMUZ A/IV 134, two pelvic fragments.

Amphibia.

ANURA Fischer von Waldheim 1813

NEOBATRACHIA Reig 1958
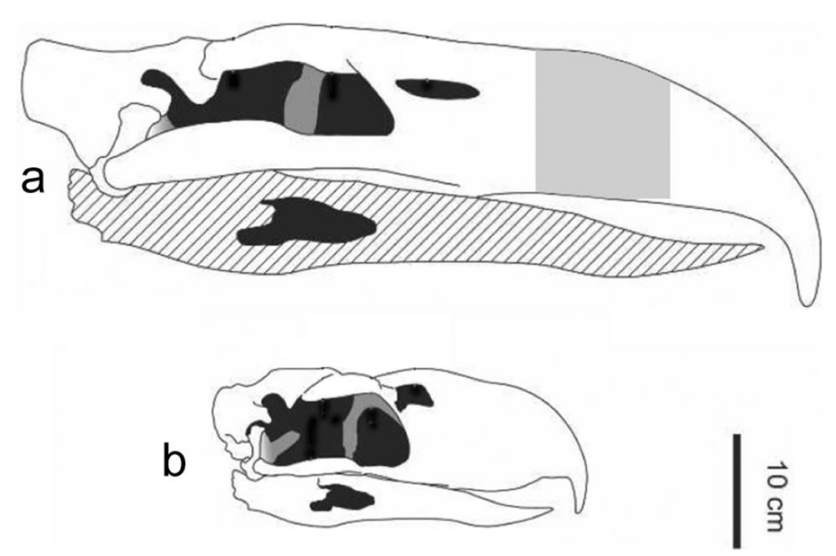

Fig. 8 Different skull shapes in Phorusrhacidae as exemplified by a Kelenken guillermoi (long, relatively low rostrum); and b Patagornis marshi (tall, relatively short rostrum). The proportions of the rostrum fragment PIMUZ A/IV 122, referred to Phorusrhacos longissimus, suggest that this taxon had a long, relatively low rostrum. The area in gray in a shows the approximate position of PIMUZ A/IV 122 on the rostrum. Modified after Bertelli et al. (2007)
AUSTRALOBATRACHIA Frost et al. 2006

CALYPTOCEPHALELLIDAE Reig 1960

\section{Cf. Calyptocephalella Strand 1928}

Referred material PIMUZ A/II 129, four broken pieces of maxilla.

Comments The maxilla is ornamented with low tubercles. All the materials have preserved the alveoli for the maxillary teeth (see Fernicola and Albino 2012).

\section{Discussion}

Twenty-eight genera and nine species of vertebrates (mammals, birds, and anurans) were identified, $94.5 \%$ of which are mammals. The taxonomic proportion of taxa matches with that from other collections from the same unit (e.g., Vizcaíno et al. 2010; Croft 2013). The most abundant taxa are notoungulates and rodents, whereas predators are the rarest forms.

The avian material is limited in number and fragmentary but most of the specimens can be referred to taxa previously described from the Santa Cruz Formation, namely Patagornis marshi and Phorusrhacos longissimus. The large rostral fragment referred to the latter taxon is of special interest, because it suggests that Ameghino's reconstruction of the skull of that giant bird (Ameghino 1895) was incorrect and that Phorusrhacos longissimus in fact had a relatively low and elongate beak similar to that of other very large phorusrhacids such as Onactornis and Kelenken, rather than a very tall but relatively short rostrum as in Patagornis and Andalgalornis (Fig. 8).

Acknowledgements We thank Guillaume Billet for aid in the identification of notoungulates; Christian Klug and Heinz Furrer for access to collections; Gabriela Schmidt for advice on taxonomic identifications; Maya Barben, Zoe Bont, Chris Brunner, Evelyn Hüppi and Nina Thürlimann, for preliminary work and sorting of specimens; and Loïc Costeur and two anonymous reviewers for their useful suggestions to improve the manuscript. Juan D. Carrillo was supported by the Swiss National Science Foundation funds P1ZHP3_165068 and P2ZHP3_174749.

\section{References}

Abello, M. A. (2007). Sistemática y bioestratigrafía de los Paucituberculata (Mammalia: marsupialia) del Cenozoico de América del Sur. Doctoral Thesis, Universidad de La Plata, Argentina. pp 381.

Abello, M. A. (2013). Analysis of dental homologies and phylogeny of Paucituberculata (Mammalia: Marsupialia). Biological Journal of the Linnean Society, 109, 441-465.

Abello, M. A., \& Rubilar-Rogers, D. (2012). Revisión del género Abderites Ameghino, 1887 (Marsupialia, Paucituberculata). Ameghiniana, 49, 164-184. 
Agnolin, F. (2007). Brontornis burmeisteri Moreno and Mercerat, un Anseriformes (Aves) gigante del Mioceno Medio de Patagonia, Argentina. Revista del museo argentino de ciencias naturales nueva serie, 9, 15-25.

Agnolin, F. (2016). A brief history of South American birds. In F. Agnolin, G. Lio, E. F. Brissón, N. R. Chimento, F. E. Novas (Eds.), Historia Evolutiva y paleobiográfica de los vertebrados de América del sur, Argentina. XXX Jornadas de Paleontología de Vertebrados. 6, 157-172.

Alston, E. R. (1876). On the classification of the order Glires. Proceedings of the Zoological Society of London, 1876, 61-98.

Alvarenga, H. M. F., \& Höfling, E. (2003). Systematic revision of the Phorusrhacidae (Aves: Ralliformes). Papéis Avulsos de Zoologia (São Paulo)., 43(4), 55-91.

Ameghino, F. (1885). Nuevos restos de mamíferos fósiles oligocenos, recogidos por el profesor Pedro Scalabrini y pertenecientes al Museo Provincial de la Ciudad del Paraná. Boletín de la Academia Nacional de Ciencias de Córdoba, 8, 5-207.

Ameghino, F. (1887). Enumeración sistemática de las especies de mamíferos fósiles coleccionados por Carlos Ameghino en los terrenos eocenos de la Patagonia y depositados en el Museo de La Plata. Boletín Museo de La Plata, 1, 26.

Ameghino, F. (1889). Contribución al conocimiento de los mamíferos fósiles de la República Argentina. Buenos Aires. Actas de la Academia Nacional de Ciencias, 6, 1028.

Ameghino, C. (1890). Exploraciones geológicas en La Patagonia. Boletín Instituto Geográfico Argentino, 11(3), 46.

Ameghino, F. (1891a). Nuevos restos de mamíferos fósiles descubiertos por Carlos Ameghino en el Eoceno inferior de Patagonia Austral. Especies nuevas, adiciones y correcciones. Revista Argentina de Historia Natural, 1, 289-328.

Ameghino, F. (1891b). Mamíferos y aves fósiles argentinos. Especies nuevas, adiciones y correcciones. Revista Argentina de Historia Natural, 1, 240-259.

Ameghino, F. (1891c). Mamíferos y aves fósiles argentinas. Especies nuevas adiciones y correcciones. Revista Argentina de Historia Natural, 1, 240-259.

Ameghino, F. (1891d). Caracteres diagnósticos de cincuenta especies nuevas de mamíferos fósiles argentinos. Revista Argentina de Historia Natural, 1, 129-167.

Ameghino, F. (1894). Enumération synoptique des espèces de mammifères fossiles des formations éocènes de Patagonie. Boletín de la Academia Nacional de Ciencias de Córdoba, 13, 259-452.

Ameghino, F. (1895). Sur les oiseaux fossiles de Patagonie. Boletín del Instituto Geográfico Argentino, 15(11-12), 501-602.

Andrews, C. W. (1899). On the extinct birds of Patagonia. The skull and skeleton of Phororhacos inflatus Ameghino. Transactions of the Zoological Society of London, 15, 55-86.

Anonymous. (1931). Obituary of Theodor Allemann. Schweizerische Bauzeitung, 98, 286.

Bennett, E. T. (1833). On the family of Chinchillidae, and on a new genus referrible [sic] to it. Proceedings of the Zoological Society of London, 1, 57-60.

Bertelli, S., Chiappe, L. M., \& Tambussi, C. (2007). A new phorusrhacid (Aves: Cariamae) from the Middle Miocene of Patagonia, Argentina. Journal of Vertebrate Paleontology, 27, 409-419.

Billet, G. (2011). Phylogeny of the Notoungulata (Mammalia) based on cranial and dental characters. Journal of Systematic Palaeontology, 9, 481-497.

Bordas, A. F. (1933). Notas sobre los Eutatinae. Nueva subfamilia extinguida de Dasypodidae. Anales del Museo Nacional de Historia Natural, 37, 583-614.

Bowdich, T. E. (1821). An analysis of the natural classifications of Mammalia for the use of students and travellers. Paris: Smith, J.
Buffetaut, E. (2013). André Tournouër (1871-1929), membre fondateur de la Société Linnéenne de la Seine Maritime et explorateur de la Patagonie. Société Linnéenne de la Seine Maritime Bulletin spécial, 2013, 21-22.

Buffetaut, E. (2014). Tertiary ground birds from Patagonia (Argentina) in the Tournouër collection of the Muséum National d'Histoire Naturelle, Paris. Bulletin de la Société Géologique de France, 185(3), 207-214.

Burmeister, H. (1879). Description physique de la République Argentine. D'après des observations personnelles et étrangères. Buenos Aires: Imprenta Paul-Émile Coni.

Burmeister, H. (1885). Examen crítico de los mamíferos y reptiles fósiles denominados por D. Augusto Bravard y mencionados en su obra precedente. Anales del Museo Nacional de Buenos Aires, 3, 95-174.

Carrillo, J. D., Amson, E., Jaramillo, C., Sánchez, R., Quiroz, L., Cuartas, C., et al. (2018). The Neogene record of Northern South American native ungulates. Washington, DC. Smithsonian Contributions to Palaeobiology, 101, 1-67.

Carrillo-Briceño, J. D., Amson, E., Zurita, A., \& Sánchez-Villagra, M. R. (2016). Hermann Karsten (1817-1908): a German naturalist in the Neotropics and the significance of his paleovertebrate collection. Fossil Record, 20, 21-36.

Cassini, G. H., Hernández Del Pino, S., Muñoz, N. A., Acosta, W. G., Fernández, M., Bargo, M. S., et al. (2017). Teeth complexity, hypsodonty and body mass in Santacrucian (early Miocene) notoungulates (Mammalia). Earth and Environmental Science Transactions of the Royal Society of Edinburgh, 106(4), 303-313.

Cione, A. L., Gasparini, G. M., Soibelzon, E., Soibelzon, L. H., \& Tonni, E. P. (2015). The great American biotic interchange: A South American perspective. New York-London: Springer Briefs in Earth System Sciences.

Cope, E. D. (1889). The edentata of North America. American Midland Naturalist, 23, 657-664.

Croft, D. A. (2013). What constitutes a fossil mammal community in the early Miocene Santa Cruz Formation? Journal of Vertebrate Paleontology, 33, 401-409.

Croft, D. A. (2016). Horned armadillos and rafting monkeys. The fascinating fossil mammals of South America. Bloomington: Indiana University PressIndiana.

Cuitiño, J. I., Fernicola, J. C., Kohn, M. J., Trayler, R., Naipauer, M., Bargo, S., Kay, R. F., \& Vizcaíno, S. F. (2016). U-Pb geochronology of the Santa Cruz Formation (early Miocene) at the Río Bote and Río Santa Cruz (southernmost Patagonia, Argentina): Implications for the correlation of fossil vertebrate localities. Journal of South American Earth Sciences, 70, 198-210.

de Paula Couto, C. (1979). Tratado de Paleomastozoologia. Rio de Janeiro: Academia Brasileira de Ciências.

Degrange, F. J., \& Tambussi, C. P. (2011). Re-examination of Psilopterus lemoinei (Moreno and Mercerat, 1891), a late early Miocene little terror bird from Patagonia (Argentina). Journal of Vertebrate Paleontology, 31, 1080-1092.

Degrange, F., Tambussi, C., Taglioretti, M., Dondas, A., \& Scaglia, F. (2015). A new Mesembriornithinae (Aves, Phorusrhacidae) provides new insights into the phylogeny and sensory capabilities of terror birds. Journal of Vertebrate Paleontology, 35(2), e912656.

Fernicola, J., \& Albino, A. (2012). Amphibians and squamate reptiles from the Santa Cruz Formation (late early Miocene), Santa Cruz Province, Argentina: Paleoenvironmental and paleobiological considerations. In S. Vizcaíno, R. Kay, \& M. Bargo (Eds.), Early Miocene Paleobiology in Patagonia: High-Latitude Paleocommunities of the Santa Cruz Formation (pp. 129-137). Cambridge: Cambridge University Press. 
Fischer von Waldheim, G. (1813). Zoognosia tabulis synopticis illustrata, in usum praelectionorem Academiae Imperialis Medico-Chirurgicae Mosquensis edita, 3rd edition (Vol. 1, p. 466). Moscow: Nicolai Sergeidis Vsevolozsiy.

Flower, W. H. (1873-1874). On a newly discovered extinct ungulate mammal from Patagonia, Homalodontotherium cunninghami. Philosophical Transactions of the Royal Society of London, 164, 173-182.

Forasiepi, A., MacPhee, R. D. E., Hernández del Pino, S., Schmidt, G. I., Amson, E., \& Grohé, C. (2016). Exceptional skull of Huayqueriana (Mammalia, Litopterna, Macraucheniidae) from the late Miocene of Argentina: anatomy, systematics, and paleobiological implications. Bulletin of the American Museum of Natural History, 404, 1-76.

Frost, D. R., Grant, T., Faivovich, J., Bain, R. H., Haas, A., Haddad, C. F. B., et al. (2006). The amphibian tree of life. Bulletin of the American Museum of Natural History, 297, 1-370.

Geiger, M., Forasiepi, A. M., Koyabu, D., \& Sánchez-Villagra, M. R. (2014). Heterochrony and post-natal growth in mammals-an examination of growth plates in limbs. Journal of Evolutionary Biology, 27(1), 98-115.

Gervais, P. (1855). Recherches sur les mammifères fossiles de l'Amérique du Sud. Expédition dans les parties centrales de l'Amérique du Sud, de Rio de Janeiro à Lima, et de Lima au Para; exécuté par ordre du Gouvernement français pendant les années 1843 à 1847 sous la direction du comte Francis de Castelnau. Zoologie, 7, 1-63.

Gray, J. E. (1821). On the natural arrangement of vertebrose animal. London Medical Repository, 5, 296-310.

Gray, J. E. (1825). Outline of an attempt at the disposition of the Mammalia into tribes and families with a list of the genera apparently appertaining to each tribe. Annals of Philosophy, n.s., ser. 2, 10, 337-344.

Gray, J. E. (1869). Catalogue of carnivorous, pachydermatous and edentates Mammalia in the British Museum. London: British Museum of Natural History.

Illiger, J.K.W. (1811). Prodromus systematic mammalium et avium additis terminis zoographicis utriusque classis. Berlin: C. Salfeld.

Jaramillo, C. (2018). Evolution of the Isthmus of Panama: Biological, Paleoceanographic and Paleoclimatological Implications. In C. Hoorn, A. Perrigo, \& A. Antonelli (Eds.), Mountains, Climate and Biodiversity: A comprehensive and up-to-date synthesis for students and researchers (pp. 323-328). Oxford: Wiley.

Johnson, J., \& Madden, R. (1997). Uruguaytheriine astrapotheres of tropical South America. In R. F. Kay, R. H. Madden, R. L. Cifelli, \& J. J. Flynn (Eds.), Vertebrate paleontology in the neotropics. The Miocene Fauna of La Venta, Colombia (pp. 355-382). Washington: Smithsonian Institution Press.

Kraglievich, L. (1926). Los grandes roedores terciarios de la Argentina y sus relaciones con ciertos géneros pleistocenos de las Antillas. Anales del Museo Nacional de Historia Natural, 34, 121-135.

Latham, J., \& Davies, H. (1795). Faunula indica; appendix. In J. R. Forster (Ed.), Zoologia indica. Halle: Secunda Verlag.

Lydekker, R. (1894). Contribution to the knowledge of the fossil vertebrates of Argentina. 3. A study of extinct Argentine ungulates. Anales del Museo de La Plata. Paleontología Argentina, 2, 1-91. (pls. 1-32).

Marshall, L. G. (1980). Systematics of the South American marsupial family Caenolestidae. Fieldiana, Geology, new series, 5, 1-145.

Marshall, L. G. (1981). Review of the Hathlyacyninae: an extinct subfamily of South American" dog-like" marsupials. Fieldiana, Geology, 7, 1-120.

Mercerat, A. (1891). Datos sobre restos de mamíferos fósiles pertenecientes a los Bruta, conservados en el Museo de La Plata y procedentes de los terrenos eocenos de Patagonia. Revista Museo La Plata, 2, 5-46.

Moreno, F. P., \& Mercerat, A. (1891). Catálogo de los pájaros fósiles de la República Argentina conservados en el Museo de Las Plata. Anales del Museo de La Plata, Paleontología Argentina, 1, 7-71.

Owen, R. (1845). Descriptive and illustrated catalogue of the fossil organic remains of Mammalia and Aves contained in the Museum of the Royal College of Surgeons of England. London: R. and J.E. Taylor.

Owen, R. (1846). Notices of some fossil mammalia of South America. British Association for the Advancement of Science, 16, 65-67.

Owen, R. (1853). Description of some species of the extinct genus Nesodon, with remarks on the primary group (Toxodontia) of the hoofed quadrupeds to which that genus is referable. Philosophical Transactions of the Royal Society of London, 143, 291-309.

Pascual, R., \& Ortiz-Jaureguizar, E. (2007). The Gondwanan and South American Episodes: Two Major and Unrelated Moments in the History of the South American Mammals. Journal of Mammalian Evolution, 14, 75-137.

Perkins, M. E., Fleagle, J. G., Heizler, M. T., Nash, B., Bown, T. M., Tauber, A. A., et al. (2012). Tephrochronology of the Miocene Santa Cruz and Pinturas formations, Argentina. In S. F. Vizcaíno, R. F. Kay, \& M. S. Bargo (Eds.), Early Miocene Paleobiology in Patagonia: High-latitude Paleocommunities of the Santa Cruz Formation (pp. 23-40). Cambridge: Cambridge University Press.

Prevosti, F. J., Forasiepi, A. M., Ercoli, M. D., \& Turazzini, G. F. (2012). Paleoecology of the mammalian carnivores of the Santa Cruz Formation (late early Miocene). In S. F. Vizcaíno, R. F. Kay, \& M. S. Bargo (Eds.), Early Miocene Paleobiology in Patagonia: High Latitude Paleocommunities of the Santa Cruz Formation (pp. 173-193). New York: Cambridge University Press.

Reig, O. A. (1958). Proposiciones para una nueva macrosistemática de los anuros. Physis, 21, 109-118.

Reig, O. A. (1960). Las relaciones genéricas del anuro chileno Calyptocephalella gayi (Dum. \& Bibr.). Actas y Trabajos del Primer Congreso Sudamericano de Zoología, 4, 113-131.

Roth, S. (1903). Los ungulados sudamericanos. Anales del Museo La Plata, Paleontología Argentina, 5, 1-36.

Scott, W. B. (1905). Mammalia of the Santa Cruz beds. Reports of the Princeton University Expeditions to Patagonia (1896-1899). Volume V, Paleontology II.

Scott, W. B. (1909). Mammalia of the Santa Cruz Beds. Reports of the Princeton University Expeditions to Patagonia (1896-1899). Volume VI, Paleontology III.

Scott, W. B. (1910). Mammalia of the Santa Cruz Beds. Reports of the Princeton University Expeditions to Patagonia (1896-1899). Volume VII, Paleontology IV.

Scott, W. B. (1928). Mammalia of the Santa Cruz Beds. Reports of the Princeton University Expeditions to Patagonia (1896-1899). Volume IV.

Simpson, G. G. (1980). Splendid isolation: the curious history of South American mammals. New Haven: Yale University Press.

Sinclair, W. J. (1906). Mammalia of the Santa Cruz beds: Marsupialia. Reports of the Princeton University, Expedition to Patagonia, 4(3), 333-460.

Sinclair, W.J., \& Farr, M. S. (1932). Aves of the Santa Cruz Beds. Reports of the Princeton University Expeditions to Patagonia (1896-1899). Volume VII.

Smith, C. H. (1842). Mammalia. Introduction to mammals. In W. Jardine (Ed.), The naturalist's library 15 (pp. 75-313). London: Chatto and Windus.

Smith, J. B., \& Dodson, P. (2003). A proposal for a standard terminology of anatomical notation and orientation in fossil 
vertebrate dentitions. Journal of Vertebrate Paleontology, 23, $1-14$.

Soria, M. F. (2001). Los Proterotheriidae (Mammalia, Litopterna), sistemática, origen y filogenia. Buenos Aires: Museo Argentino de Ciencias Naturales "Bernardino Rivadavia", Monografías.

Strand, E. (1928). Miscellanea nomenclatorica zoological et palaeontologica I-II. Archiv für Naturgeschichte, 92, 30-75.

Thomas, O. (1897). On the genera of rodents: an attempt to bring up to date the current arrangement of the order. Proceedings of the Zoological Society of London, 1896, 1012-1028.

Tournouër, A. (1922). Recherches paléontologiques en Patagonie. Bulletin mensuel de la Société Linnéenne de la Seine Maritime, 8(9), 237-239.

Tullberg, T. (1899). Über das System der Nagethiere: eine phylogenetische Studie. Nova Acta Regiae Societatis Scientarium Upsaliensis, 18, 1-514.

Vera, B. N., Fornasiero, M., \& Del Favero, L. (2015). The Egidio Feruglio's collection in the Museum of Geology and Palaeontology of the University of Padova: its importance to the knowledge of Cenozoic Mammals from South America. Museologia Scientifica., 9, 35-44.

Verheyen, R. (1957). Contribution au démembrement de l'ordo artificiel des Gruiformes (Peters, 1934). II. Les Cariamiformes. Bulletin de l'Institut Royal des Sciences Naturelles de Belgique, $39,1-7$.

Vizcaíno, S. F. (2011). Cartas para Florentino desde la Patagonia. Crónica de la correspondencia édita entre los hermanos Ameghino (1887-1902). In Fernicola J. C., Prieto A. R. and Lazo D. G. (eds), Asociación Paleontológica Argentina, Buenos Aires. Vida y obra de Florentino Ameghino. Publicación especial $n^{\circ} 12,51-57$.

Vizcaíno, S. F., Bargo, M. S., Kay, R. F., Fariña, R. A., Di Giacomo, M., Perry, J. M. G., et al. (2010). A baseline paleoecological study for the Santa Cruz Formation (Late-Early Miocene) at the Atlantic Coast of Patagonia, Argentina. Palaeogeography, Palaeoclimatology, Palaeoecology, 292(3-4), 507-519.

Vizcaíno, S. F., De Iuliis, G., Brinkman, P. D., Kay, R. F., \& Brinkman, D. L. (2017). On an album of photographs recording fossils in the "Old collections" of the Museo de la Plata and Ameghino's private collection at the beginning of the XX century. Publicación Electrónica de la Asociación Paleontológica Argentina, 17(1), 14-23.

Vizcaino, S. F., \& Farina, R. A. (1997). Diet and locomotion of the armadillo Peltephilus a new view. Oslo. Lethaia, 30, 79-86.

Vizcaíno, S. F., Kay, R. F., \& Bargo, S. (2012). Early Miocene paleobiology in Patagonia. High-Latitude Paleocommunities of the Santa Cruz Formation. Cambridge: Cambridge University Press.

Waterhouse, G. R. (1839). Observations on the Rodentia, with a view to point out groups as indicated by the structure of the crania in this order of mammals. Magazine of Natural History, 3, 90-96.

Wilf, P., Cúneo, R. N., Escapa, I. H., Pol, D., \& Woodburne, M. O. (2013). Splendid and seldom isolated: The paleobiogeography of Patagonia. Annual Review of Earth and Planetary Sciences, 41(1), 561-603.

Winge, H. (1923). Pattedyr-slaegter. 1-Monotremata, Marsupialia, Insectivora, Chiroptera, Edentata. Copenhagen: Hagarup.

Wood, A. E. (1955). A revised classification of the rodents. Journal of Mammalogy, 36, 165-187.

Worthy, T. H., Degrange, F. J., Handley, W. D., \& Lee, M. S. Y. (2017). The evolution of giant flightless birds and novel phylogenetic relationships for extinct fowl (Aves, Galloanseres). Royal Society Open Science., 4, 170975.

Zittel, K. A. (1893). Handbuch der Palaeontologie, IV. Bd. Vertebrata (Mammalia). Munich: R. Oldenbourg.

\section{Affiliations}

\section{Daniel Zurita-Altamirano ${ }^{1} \cdot$ Eric Buffetaut $^{2,3} \cdot$ Analía M. Forasiepi $^{4} \cdot$ Alejandro Kramarz $^{5}$ - Juan D. Carrillo ${ }^{6,7}$ (D)

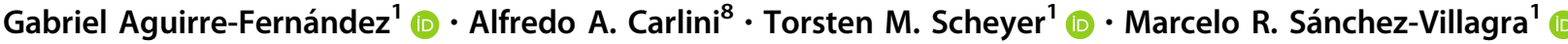

1 University of Zurich, Paleontological Institute and Museum, Zurich, Switzerland

2 CNRS (UMR 8538), Laboratoire de Géologie de l'Ecole Normale Supérieure, PSL Research University, Paris, France

3 Palaeontological Research and Education Centre, Maha Sarakham University, Maha Sarakham, Thailand

4 IANIGLA, CCT-CONICET, Mendoza, Argentina
5 Museo Argentino de Ciencias Naturales "Bernardino Rivadavia”, Buenos Aires, Argentina

6 Department of Biological and Environmental Sciences, University of Gothenburg, Gothenburg, Sweden

7 Gothenburg Global Biodiversity Centre, Gothenburg, Sweden

8 Laboratorio de Morfología Evolutiva y Desarrollo (MORPHOS), and Div. Paleontología de Vertebrados, Museo de la Plata, UNLP, La Plata, Argentina 